\title{
EDITORIAL
}

\section{Changes With Time and Our Partial Farewell}

\section{Microhistory}

At a small UNESCO Conference at Kevo in the North of Finland in the Summer 1966 we had a sudden realization, amounting to a kind of vision, that if the world's human populations went on growing and acting as profligately as they had been doing in recent decades, more and more ecodisasters would be inevitable and ultimately there would be an end to much of what was best in our civilization and conceivably to all life on Earth. Thereupon we decided that it was our solemn duty to do all we possibly could henceforth to warn humanity of these grave dangers - ultimately to life itself, as it was emerging that it had seemingly no other source than Planet Earth. We subsequently had a vivid dream of gigantic aircraft, at the ends of too numerous criss-crossing contrails, dropping perpendicularly out of the hazy and polluted sky. So having been brought up on family farms, studied ecology under the pioneering A.G. Tansley at Oxford, and later had the experience of developing and editing an international journal, our first action following that quite shocking realization was to establish a Journal of global perspective and readership that would carry the message quite clearly of the impending danger to The Biosphere as the sole habitat of Humankind and Nature. For such a campaign our resolve was only strengthened by religious and other factions whose adherents were apt to dismiss our warning against 'too many people' as 'sheer nonsense'.

Consequently the next year found us doing what we could about winding up prior commitments* and instituting the needed pioneering Journal, by now named Biological Conservation, of which we started publication in 1968. In those early days we were much encouraged by the late Sir Hugh Elliott, then Secretary-General of IUCN, which latter, increasingly world-leading organization, had emerged from plans that we had discussed with the late Harold Coolidge and others in Washington, DC, when we were back at Yale and Harvard in the late 1940s and early 1950s. Much later but with the same ultimate if grandiose objective of 'saving the world' we held and edited or co-edited a pioneering series of four International Conferences on Environmental Future (ICEFs), each of which resulted in a substantial volume of Proceedings, and organized the World Council For The Biosphere (WCB), subsequently instituting the global annual reminder of Biosphere Day, etc.

After editing Biological Conservation - single-handed apart from a widespread corps of Consultant Editors - for its first five years and volumes during which we 'split off' Environmental Pollution after finding for it a suitable Editor and supplying him with some materials when needed early-on, we felt that the former Journal was sufficiently established to pass on to other Editorship (under which it is now in its 74th volume), so that we could embark on a more predominantly ecological/environmental journal which we had planned as being 'devoted to maintaining global viability through exposing and countering environmental deterioration resulting from human population-pressure and unwise technology.'

\section{Enter Our Journal}

Thus came into being Environmental Conservation, which started publication with its Spring issue of 1974 and has appeared ever since as an illustrated volume of some 400 pages (now for long the actual number if we include the informative covers), the annual four issues of which correspond to the seasons of the year in the northern hemisphere. Each issue has consisted - after the more 'experimental' early ones - of an opening Editorial Section, followed by usually seven or eight specialist refereed scientific or allied papers, and then four other regular sections of Short Communications \& Reports, Notes, News \& Comments, Conferences \& Meetings, and Book Reviews \& Notices. Each issue thus publishes between 40 and 50 separate items, most of which are signed by their Authors (with addresses for contact) and almost all of which are original. We have also published two instalments (1974-86 and 1987-8) of an Index of Titles and Authors in Environmental Conservation, and plan a final one, after due completion of the present volume, to bring matters fully up-to-date - so covering our many years of Editorship and also, it has been remarked, at least with its predecessor Biological Conservation, "practically the development of the environmental/ conservational movement.'

The Journal is owned by the (originally ad hoc) Foundation for Environmental Conservation (FEC) but now, after 22 years of our founding Editorship, it is in need of modernization and passage to a non-profit publisher which will enable the new Environmental Conservation to benefit the Foundation from its financial potential while making it available to individuals at less than half the institutional subscription price.

\section{New Editor and Publisher}

Happily chosen as Editor is Dr N.V.C. Polunin, of the Department of Marine Sciences \& Coastal Management, Faculty of Agriculture \& Biological Sciences, University of Newcastle, Newcastle upon Tyne NE1

\footnotetext{
* Such as a contract for three more volumes on Arctic Botany and Ecology to be published by Oxford University Press's prestigious Clarendon Press, for which publication it was decided the time had passed since our years of helping to plan and establish (inter alia as designer of the layout and first Dean of Science) a major university in Nigeria for which we still felt some responsibility.
} 
7RU, England, UK, to whom all future submissions should be sent and editorial questions addressed. Also happily chosen as the global publisher, is the Journals Department, Cambridge University Press, The Edinburgh Building, Shaftesbury Road, Cambridge CB2 2RU, England, UK (see Announcement below). Viability being of anxious concern in the present, uncertain times, it is interesting to note that Cambridge University Press is the oldest surviving press in the world.

Yes of course it will be a wrench after more than a quarter of a century to be no longer the Editor of a leading journal of world-wide circulation and evident influence on a vital topic or, for the last 22 years, duality of topics. But although passing on primary responsibility to a well-qualified and keen family member, we'll henceforth, as latterly, be looking after the section of Book Reviews, receiving review copies of books and passing on the residue each year to IUCN and/or the International Academy of the Environment (based, respectively, near to and in Geneva), serving on the Board of Advisory Editors with special responsibility for matters pertaining to The Biosphere, and in those and some other ways - such as administering the owning Foundation for Environmental Conservation - serving the cause of what we confidently expect to be an everstronger and more influential journal. ${ }^{\dagger}$

NiCHOLAS POLUNIN

16 November 1995

\footnotetext{
tWe also aspire to foster the long-dreamed-of global network of Biosphere Clubs so that they become recognized and treated as effective environmental/conservational watch-dogs - duly guided in policy matters by a revived World Council For The Biosphere - while seeking a Biosphere Fund sufficient to award a major Biosphere Prize and 5 or 6 satellite prizes each year to be announced on Biosphere Day.
}

\section{ANNOUNCEMENT}

\section{Change in Publisher of Environmental Conservation to Cambridge University Press*}

A S of 1 January 1996, the Journal Environmental Conservation will be published by Cambridge University Press. Correspondence concerning subscriptions, permissions, and other matters related to the publication and distribution of the Journal, should henceforth be directed to:

\section{In the UK and rest of the world:}

\author{
Journals Department \\ Cambridge University Press \\ The Edinburgh Building \\ Shaftesbury Road \\ Cambridge CB2 2RU \\ England, UK
}

Tel. (+44) 1223312393
Fax: (+44) 1223315052

\section{In the USA, Canada, and Mexico:}

Journals Department

Cambridge University Press

40 West 20th Street

New York

NY 10011-4211

USA

$$
\begin{aligned}
& \text { Tel. +1 (212) } 9243900 \\
& \text { Fax: +1 (212) } 6913239
\end{aligned}
$$

\footnotetext{
* This change promises to benefit the owning Foundation for Environmental Conservation and its capabilities of helping the Environmental/Conservational movement as, instead of having to pay most of the overheads of producing each issue of Environmental Conservation, for the substantial benefit of its latterly mere distributor and with the Editor giving his entire services for the good of the cause, the Foundation will receive revenues from the not-for-profit oldest press in the world. Apart from voluntary donations and grants towards reimbursement of the cost of editing and publishing their papers from satisfied Authors or their institutions which it is hoped will continue, the amounts received by the Foundation will depend mainly on subscriptions to its Journal. These are expected to increase greatly in the hands of this distinguished Publisher which is to offer subscriptions to individuals at less than half of the institutional price. Meanwhile the Foundation's headquarters and most overheads are contributed by its President, who plans to continue in that capacity just as long as he is able to and wanted.
} 